\title{
War as nothing but a duel: war as an institution and the construction of the Western military profession
}

DOI 10.2478/jms-2018-0003

Received December 18, 2017; accepted June 20, 2018

\begin{abstract}
Like all repetitive human interaction, even war has been institutionalized and fought according to conventions and norms. Historically, this institutionalization is apparent from the way war has been compared to the duel, first in the 14th century and most famously by Carl von Clausewitz 5 centuries later. This article continues this train of thought and argues that the observed limits of Western "professional orthodoxy" and "strategic vocabulary" can be traced to how war has been institutionalized by the military profession. This offers an alternative explanation to the prevailing views of why the West has struggled in contemporary wars: it is the fundamental mismatch between these professional norms in the West and those held by their opponents that forms the biggest asymmetry in contemporary war. As this asymmetry is unlikely to disappear, these professional norms need to be reconsidered: just like the aristocracy with the duel by the late 19th century, the Western military profession appears stuck in an institution that is increasingly becoming obsolete. Without such reconsideration, the attainment of decision the central strategic objective in war - and hence victory in future wars will remain uncertain.
\end{abstract}

Keywords: Clausewitz, cultural sociology, duel, institutions, military culture, strategy, war

\section{Introduction: why does the West not win?}

In his 1995 essay, A. J. Bacevich wrote about the "persistent limitations of professional orthodoxy" within the US

\footnotetext{
*Corresponding author: Ilmari Käihkö, Department of Security, Strategy and Leadership, Swedish Defence University, Östermalm, Stockholm, Sweden; Department of Sociology, Uppsala University, Uppsala, Sweden, E-mail: ilmari.kaihko@fhs.se
}

armed forces, which provided enemies with vulnerabilities ripe to be exploited (1995: 60). This was a problem that Hew Strachan returned to when he argued that the end of the Cold War made the past decades' strategic vocabulary obsolete (2013: 41). Arguably, the polarization between the two superpowers and the mutual possession of nuclear weapons meant that war had lost its rationality: no justification could warrant the resulting degree of death and destruction of nuclear war. As a result, all other strategic thinking paled in comparison to deterrence and avoiding not fighting - war. Yet, when the threat of Armageddon passed, threats that had previously been deemed insignificant gained in importance. This was especially the case with nonstate actors.

While these actors were not new, it was only the terror attacks in September 2001 and the following declaration of a global war against terror that brought them to the center of the attention of international security. Yet, as has since become clear, despite the discovery of numerous prefixes to war, no new strategic vocabulary has been devised to help in dealing with these actors. As Jan Willem Honig (2016: 275-276) has argued, the militaries of developed states continue to "labour under the tyranny of outmoded ideas of how war and strategy work" to the point that mere adaptation "without thinking about war and strategy in novel ways" has resulted in limited success in recent wars in places like Afghanistan and Iraq. ${ }^{1}$

What is at stake here is nothing less than victory and defeat in future wars. Yet, while Bacevich (1995: 60) saw

1 Shifting focus from developments in Afghanistan to the primacy of standing together with North Atlantic Treaty Organization (NATO) allies or highlighting the lessons useful in national defence (as the Norwegian and Swedish official inquiries, respectively, attempted to do) is beside the point here: no later reprioritization will change the fact that the NATO-led coalition struggled against the deteriorating situation (Departementenes sikkerhets- og serviceorganisasjon 2016; Regeringen 2017), and that the European responses largely followed the same patterns (Honig and Käihkö 2014). 
that these professional limitations were not new, he pessimistically saw that "most of it is unavoidable". This article takes a slightly more positive take on the issue. None of this may be new, but it is not impossible to reinvent this professional vocabulary. The aim of this paper is thus to contribute to this debate through the investigation of the most central institution of the military profession - war. In more concrete terms, this paper follows the observation made by Philip Smith (2005: 4), who argued that "war is not just about culture, but it is all about culture". While admittedly taking a very extreme view, as he disregarded the material realities of war, Smith's observation nevertheless nicely summed up an emerging trend within the sociological study of war, which emphasizes normative dimensions and which clearly draws from the study of culture (Keegan 1994; Legro 1995; Farrell 2005; Kramer 2008; Van Creveld 2009). While Smith's focus was public discourse, he rightfully saw that cultural explanations have been lacking even when it comes to conduct of war and military life alike. As a result, he argued that, "military action is taken as a paradigm exemplar of what efficient, goal directed but ultimately meaningless collective social action looks like" (Smith 2005: 5-6). Yet, as suggested by his idea of cultural systems (Smith 2005: 11), orthodox professional norms that limit available courses of action have become a core problem in recent wars. After all - and as several contemporary wars well illustrate - it is not only tactical battlefield proficiency that delivers victory. Just like Thomas Schelling (1980) attributed the nonuse of nuclear weapons during the Cold War to shared conventions, this article argues that short of complete annihilation, a shared understanding of war is required before violence can lead to conflict resolution and durable peace.

Recent experiences in armed conflicts highlight the fundamental discrepancy between the understandings of war held by the Western military profession ${ }^{2}$ on the one hand and those of its enemies and allies on the other. Previous research has illustrated the importance of these kinds of collective military professional conventions. For instance, Jeffrey Legro (1995) has argued that ideas of war and organizational culture within military bureaucracies trumped the preferences of national leaders on the use of force during the Second World War. This article extends this finding to the Western military profession and argues

2 These commonalities echo James Gow's (2005: 7) observation about the West as a construction "created by factors such as geography, history, culture, politics, religion, philosophy, and identity" fundamentally based on exclusivity. Hence, the West refers to the developed states that have organized themselves (including their militaries) according to these shared conventions and that perceive others who have not done so as distinct. that it possesses its own norms, based on an understanding of war comparable to another institution, that of the duel. This is, however, not to say that war in practice equals to a duel, a notion questioned by the realities of contemporary war. Nevertheless, and as motivated by Carl von Clausewitz's (2004: 1) famous maxim that "war is nothing but a duel on an extensive scale", it appears that the military profession is increasingly stuck in a similar situation with contemporary war as the aristocracy was with the duel by the late 19th century - clinging to an institution that is increasingly becoming obsolete.

This case of cultural specificity is suggested not only by the struggles against irregular opponents who adhere to different conventions (hence the notion of "unconventional" war), but even by the recent conceptual confusion apparent in prefixes to war, such as hybrid. While the concept clearly illustrates the crisis of the deeply held understanding of war as something that can be executed in an apolitical and linear manner, it has resulted in limited reevaluation of the concept of war or the responsibilities of the military profession. The contribution of drawing parallels between duel and war as comparable institutions suggests that the obsolete professional vocabulary too can be rethought to better match the demands of contemporary warfare, by which I simply mean armed conflict. In fact, this may well be necessary in order to win in future wars.

This article proceeds in six steps. The following section discusses war as an institution, as well as the necessary caveats of the argument carried here. The comparison between duel and war can be historically traced to 14th-century thinkers, who were looking for a stable foundation that enabled the institutionalization of war. Yet, it is far from certain that war is understood in the same manner everywhere and by everyone: it should hence not be investigated primarily as a Eurocentric legal institution. The third section continues this train of thought and departs from the classic comparison of war as nothing but a duel, or an institution. Similar institutionalization of war is evident in increasingly uniform vocabulary, norms, and organization of Western militaries to the extent that by the end of the First World War, it became possible to speak of $a$ Western military profession, united by a shared understanding of war. The fourth section focuses on comparing the duel-like understanding of war that both gives a positive narrative and internal cohesion to the military profession and makes war an effective institution of conflict resolution. The fifth section argues that this view of war risks becoming obsolete. This is illustrated by a lack of mutual understanding and recognition between opponents and, ultimately, lack of decision in war. Lack of 
mutual recognition leads to existential war, whereas the absence of decision leads to its perpetuation. In conclusion, as the asymmetry between norms held by Western military professionals and others is unlikely to disappear, these norms need to be reconsidered, lest war will continue to lead to ambiguous outcomes in the future.

\section{War as an institution}

Perhaps referring to the etymology of duel as the Latin duellum - an archaic form of bellum, or war (Oxford English Dictionary 2016) - in the second paragraph of his first book On War, Carl von Clausewitz wrote that "war is nothing but a duel on an extensive scale" (2004: 1). While Clausewitz admittedly nicked this idea (together with the name of his masterpiece) from his colleague Rühle von Lilienstern (Heuser 2010a: 172-174), this comparison is of much older vintage. The close connection between war and duel can be traced to the 14th-century Italian lawyer John of Legnano (also known as Giovanni da Legnano), who synthesized much of earlier legal thought in his Tractatus de bello, de represaliis et de duello (Holland 1917). As the title of this work already suggests, he contributed to what Stephen Neff (2008: 137) has called the contractual theory of war, which portrayed "war as a contract between two parties to settle a quarrel by force of arms" in a duellike manner.

The mention of contract alone assumes the existence of institutions, used to order repetitive social life. Considering mankind's long history as well as the unpredictability and high stakes inherent in organized violence, it should hardly be surprising that even this kind of interaction has been institutionalized. Following Seumas Miller, institutions involve differentiated and repetitive actions performed by different actors, which furthermore comply with systems of conventions and social norms (Miller 2010: 23-24). Focusing on international institutions, Kalevi Holsti in turn emphasizes historical change and sees that they "represent patterned (typical) actions and interactions of states, the norms, rules, and principles that guide (or fail to guide) them, and the major ideas and beliefs of a historical era" (Holsti 2004: 18). Institutions thus prescribe interaction, with a good empirical example coming from the way armies in the past ensured that they would come to blows by deciding on a place and time they would battle, often finding open areas where the fighting forces could neatly spread out before engaging each other. It is, however, equally important to emphasize that institutionalization of war is important for other audiences as well. Institutes spell out the rights and responsibilities of different groups, including belligerents on both sides, domestic noncombatant audiences, and even third parties. Nevertheless, institutionalization also requires a recognizable shape. This shape was provided by duel. As Mary Douglas has argued (1986: 112):

Any institution that is going to keep its shape needs to gain legitimacy by distinctive grounding in nature and in reason: then it affords to its members a set of analogies with which to explore the world and with which to justify the naturalness and reasonableness of the instituted rules, and it can keep its identifiable continuing form.

Yet, it should be immediately cautioned that one should not begin to investigate the institution of war from the Eurocentric perspective of sovereign statehood, as Holsti does. This perspective departs from the understanding of war as a legal institution in the sense that framing something as war immediately subjects all interaction to a legal structure. As David Kennedy has argued, law is embedded in the Western concept of war to the point that war has become, first and foremost, a legal institution (Kennedy 2006). Yet, according to Nathaniel Berman (2004) - and contrary to what is often believed - laws of war do not primarily seek to oppose violence, but to construct it through the privileging of certain forms of violence over others. In other words, these laws are crafted by those in position of power to guarantee that they remain there. The Eurocentric perspective thus emphasizes Max Weber's idea of a sovereign state as the holder of monopoly of violence, which in effect legitimizes state-sponsored violence and delegitimizes violence used by other actors. In this sense, the word military itself is Eurocentric and suggests that military theory forms one narrow field within the broader interdisciplinary war studies.

While often taken as a natural category, military is anything but. It only appeared as an English noun in the early 18th century (Oxford English Dictionary 2002), when armies began to move under state tutelage and to wear king's colors instead of their own. Successively, matters related to war were separated from the rest of the society and delegated to a dedicated bureaucracy (Howard 2001). While, in contemporary times, civilian forms the antithesis of military, on closer investigation, even this category is a recent one. As Amanda Alexander has described, the term civilian began to first be used to denote nonmilitary persons in the mid-19th century but was only legalized in international law after the First World War in the 1920s. Before that and after the French revolution, it was rather the citizen who offered the antithesis to soldiers, although in a much more ambiguous way: citizens became enemies 
as soon as war was declared. The question was rather whether civilians were active or passiveenemies(Alexander 2007). As understood today, the categories of civilian and military alike are thus unprecedented and historically recent constructions, increasingly codified into law.

Yet, just like legal frameworks have been constructed around war in the West, so has the Western military profession formed shared norms around a particular understanding of what war is and how it should be waged. A concrete example of this comes from the way the fighting in places like Afghanistan are thought of as "operations", rather than wars. Even if often declared as involving "warlike" situations, the term nevertheless suggests a lesser form of activity, as made clear in the moniker "military operations other than war", coined in the mid-1990s (Joint Chiefs of Staff 1995). Considering that many of the activities assigned to this broad category have since become the main activities of Western militaries and that the United States has to date only declared five wars, it is clear that studying war from a strict legal perspective hides more of the phenomenon than reveals.

It is nevertheless, first and foremost, in this legal construction of war where one finds Bacevich's professional orthodoxy, which has become a limiting factor in contemporary war. As elaborated in a companion piece, war can be constructed in varying ways (Käihkö 2018). This suggests that Eurocentrism and the normative idea of legitimacy associated with the state may have become part of the problem. For analytical reasons alone, the perspective needs to be broadened. So while this article approaches war as an institution formed by the Western military profession, this understanding is far from the only way to understand war: war is an institution that is always regulated by norms and conventions, whether these have been codified into law or not. Ultimately, this is also the difference between legal and social institutions, where the former can be understood as a formalized subcategory of the latter.

\section{War as nothing but a duel}

For some, the most obvious way to begin the investigation of military professional norms and orthodoxies would be doctrines. After all, doctrines are written for internal use as a way to distribute a way of how war should be thought about and fought, hence reproducing the "right" kind of behavior (Angstrom and Widen 2016; Honig 2016). The problem with this view, however, is that doctrines tend to be unreflective when it comes to their assumptions.
The fact that they are written to an audience with similar background means that there is typically little, if any, consideration for questioning deeply held norms. Rather than questioning, they are typically confirming and conforming.

An alternative way to investigate these norms is to begin with the most fundamental understandings of war and follow Clausewitz's characterization of it as a duel. Here, two different interpretations of duel arise. The first one sees duel as nothing more than a trial of strength. According to Antulio Echevarria (2013: 63), while the German Zweikampf is usually translated to English as duel and this meaning was common in the time Clausewitz wrote his life's work, it is more appropriate to translate this to "personal or individual combat". This view then sees Clausewitz's choice of metaphor as merely a way to illustrate and emphasize the reciprocal and violent nature of war between living combatants, instead of sterile plans that saw war as a natural science that could construct mathematical formulas to defeat opponents, without considering that these would have a say in it all.

The second and more interesting interpretation of the duel emphasizes the view of war as an institution, which countered what Clausewitz identified as the core dynamic of war, or escalation toward extremities. Yet, Clausewitz also noted that "social conditions" within and between states influenced these dynamics (2004: 2). On a more micro level, adherence to norms of honor and duty was an almost absolute requirement for certain circles during Clausewitz's time. Especially within the German officer corps, dueling was closely connected to personal honor, which in turn reflected the honor of the military. In this sense, internalized ideas of honor became a way to form internal cohesion within the ranks, as well as to distinguish officers from outsiders. The same ideas, however, also left officers who felt offended no alternative than to resort to a duel, lest they face social isolation (Frevert 1995: 46-50).

These ideas of honor are also present in Clausewitz's early political outlook, which underpins his theoretical writing. The best example is his 1812 essay Bekenntnissdenkschrift (memorial of confession or belief), written in the aftermath of Prussia's humiliating defeat against Napoleon in 1806 and the approaching war against Russia (Clausewitz 2015: 169-216). After Prussia was forced into an alliance with France, it would commit 20,000 soldiers to the French side. This was unacceptable for Clausewitz and the coterie of military reformers he belonged to. He began his essay by comparing war to an individual duel, where the act itself was more important than the outcome. After this, he called his native Prussia to 
rise against Napoleon to preserve its honor. When his call was not heeded, Clausewitz resigned and joined the Russians. While Clausewitz saw that Prussia was obliged by its honor to rise against Napoleon, this would almost certainly have been a futile attempt that would have led to a costly defeat. This defeat, argued Clausewitz, would merely hasten the inevitable destruction of Prussia. Yet, the only chance of reincarnation would come from fulfilling the moral obligation of rising up in order to reclaim Prussia's honor. It is thus difficult to see war in this particular instance as a rational instrument of state interest. Rather, it was an act of self-realization. As Andreas Herberg-Rothe argues, the essay thus emphasizes the existential view of war, where the moral existence weighed more than the physical (Herberg-Rothe 2011: 71-72; Paret 2007: 213-219). While Clausewitz's position later changed, his essay underscores the normative dimension of war which, as noted, may well be a factor behind the recent problems of winning in war.

The existence of these kinds of norms was certainly not only limited to Clausewitz and his 19th-century contemporaries. A century later, the chief of operations of the German Reichswehr army, Chief of Staff Joachim von Stülpnagel, had remarkably similar views regarding future war: perceived inevitable, it would result in either victory or catastrophe. Like Clausewitz (Heuser 2010b), Stülpnagel advocated arming the people. Yet, again like Clausewitz, he expected the outcome of the war to be nothing less than honorable self-destruction (Vardi 2010: 200-201). According to Gil-li Vardi, these views were shared by many, or perhaps most, German officers at the time. They were simply unable to find nonmilitary solutions to the strategic problems faced by Germany at the time, to the extent that "the Reichswehr's professional viewpoint left its leadership no other choice" (Vardi 2010: 202). In other words, and just like with Smith's cultural systems (Smith 2005, 11), their professional norms effectively limited their available courses of action.

This imperative of military victory regardless of cost has been sometimes inaccurately understood as a part of Germany's Sonderweg or "singularity of destructiveness" (Kramer 2008). The concept of military (or the broader strategic) culture too presumes significant national differences. Views of national differences are of course only enhanced by the fact that Western militaries are tightly incorporated within their respective states to the point of becoming just one of its many bureaucracies. Yet, the fact that nationalizing of military establishments has been followed by a parallel process of internationalization is best visible in legal frameworks. As Kennedy argues, the past 2 centuries have seen distinctly national rules of war become influenced by international law to the point of resulting in a shared legal vocabulary, internalized by the Western military profession (Kennedy 2006: 7).

While Clausewitz too recognized that the force whose use constitutes war came with "self-imposed restrictions" in the form of international law, he also noted that these were "almost imperceptible and hardly worth mentioning" (Clausewitz 2004: 1). If this was ever true, Clausewitz's view has since become outdated. First, the development of international law has certainly become much more prominent in contemporary wars than in those of the 19th century. Secondly, and more importantly for the argument made in this paper, these self-imposed restrictions are hardly limited to international law. The Western military profession has produced a shared legal vocabulary and has simultaneously acquired one related to war and warfare. This is a process that was already ongoing when the professional military education increased significantly in the early 19th century, ${ }^{3}$ but which, by the end of that century, had resulted in a much more uniform military profession in Europe. This is clear from the view of the American Civil War, where European military thinkers recognized unprofessional incompetence, instead of an opportunity to analyze what foreboded future war. The Prussian performance in its wars against Denmark, Austria, and France contrasted with this bloody stalemate. Interpreted as proof of Prussian military excellence, it was closely studied and imitated by other continental powers to the best of their ability during the following decades (McNeill 1983: 242-253). Wars and the natural selection inherent in them have often led to standardization and universalization. Emil Lederer (2006) observed that the First World War forced states to isomorph their organization and strategy. Connected to the latter, Stephen Biddle (2004: 28) saw that the war resulted in what he calls a modern system of force employment. Based on "a stable and essentially transnational body of ideas on the methods needed to operate effectively in the face of radically lethal modern weapons", it "defined the standard for successful military operations throughout the post-1918 era".

Although the European military profession became increasingly uniform by the late 19th century, latest by the end of the First World War, it became possible to speak of $a$ Western military profession, united by a shared understanding of war. In other words, and as hinted by Strachan in the quote that began this article, the Western military

3 See the discussion of early modern European armies as transnational "homogenizing agents" (Wishon 2013), as well as other papers (Duffy 1987; Holsti 2004: 277ff; Strachan 2006). On how Western military norms were exported elsewhere, see Ralston (1990). 
profession is formed around a common understanding of what war is and how it should be fought. This is clear when one considers Western armies and what they do. They are composed in the same manner, with comparable units consisting of roughly the same number of soldiers trained roughly by same methods, uniformed and equipped in roughly the same way, serving states and operating in roughly the same manner, described in a shared professional vocabulary (e.g., see Clausewitz 2004: 190). ${ }^{4}$ This vocabulary - and with it, the professional norms - was then further disseminated through military education and doctrines. International military training programs have further been used to spread these views beyond the Western world, resulting in - at times, uncritical attempts to transplant Western ideas to contexts such as Afghanistan, where they remain foreign. ${ }^{5}$

As with any institution, rules and norms that regulate behavior are both necessary and unavoidable even in war. In fact, because violence involves transitions and crossing boundaries between life and death, Anton Blok (2001: 109) sees that it is characterized by ritualization, "rules and prescriptions, etiquette and protocol". This said, Martin Van Creveld has noted that different sets of rules for fighting wars have been used in different situations and against different opponents. One way to do so was to divide opponents into those who have the right to wage war and those who do not. Reciprocity follows both categories: those waging war for legitimate reasons and through legitimate ways are treated differently from those who do not. Whereas those deemed equal are seen to simply carry out their own responsibilities as servants of a sovereign state and generally treated well, showing restraint against others might question one's own legitimacy, as well as encourage breaking the norms one seeks to maintain. Even here, norms exist in order to limit escalation, and infringing them was deemed to slight against the warrior ethos or honor (Van Creveld 2009: 132-136). This is well captured by the training school in "ungentlemanly warfare" established in Britain in 1940 by veterans of the Spanish Civil War, who sought to teach the use of guerrilla tactics against the expected German invasion (Beckett 2001: 20-21). A similar point was made by Charles Callwell (1996 [1906]: 23), who emphasized that while "certain rules of conduct exist which are universally accepted... irregular warfare must generally be carried out on a method totally

4 Hence leading to the widespread ideas of a distinctly Western way of war, which often emphasizes the importance of culture. For instance, see Keegan (1994).

5 Mogelson (2013) offers an interesting snapshot of how the war in Afghanistan looked without Westerners. different from the stereotyped system". More recently, other prefixes to war - such as asymmetric, hybrid, and unconventional - similarly suggest the existence of an ideal war fought according to these kinds of standardized or "gentlemanly" conventions, and the desperation when opponents decline to do so. In other words, it is problematic to compartmentalize war in the sense of having one category (the regular or conventional) that the military wants to fight, when the vast majority of wars are not of this category. While this was the case already during Callwell's time, the same became apparent with recent counterinsurgency efforts, which questioned whether war can be waged in an apolitical manner where violence became nothing more than a technical activity (Ucko 2012).

While it may indeed be unfair to ask officers to include politics to their already difficult tasks of warfighting, the question is whether this can be avoided. After all, the alternative would essentially mean that military professionals get to decide what kind of war they embark upon, and that while waging it, they can isolate politics from it. This kind of thinking that one often encounters in interactions with Western military professionals, especially in - but even outside - classrooms, suggests strong preferences that match with professional norms, and at worst constrain military thinking within tight bounds that hark to an ideal of war as a duel between equals. The following parts of this paper investigate this ideal way in which wars should be fought and how this idea has become obsolete.

\section{War as a duel between individuals and between collectives}

So far, I have traced the formation of a Western military profession with its standardized ideas of what war is and its role in it. This section discusses the norms possessed by this profession, based on an understanding of war comparable to duel. Historically, this conception of war has provided a suitable institution for achieving the main goal of war: political decision. Yet, as Emile Simpson has argued, it is questionable whether war as an interpretive framework (or, as investigated here, an institution) is universally understood in the same way. According to Simpson (2013), war might have a grammar, but it does not necessarily speak the same language. In other words, war might not be mutually intelligible. Simply put, different views of war lead to the lack of prescriptions to organize interaction but also to a lack of mutual recognition. 
This section of the paper discusses the benefits of the duel as an effective institution for conflict resolution between both individuals and collectives, with the next section concentrating on the consequences of this idea becoming obsolete.

Historically, a duel is an institution where two equals resolve their disagreement in a way that excludes the masses. It is fought on equal terms between two sides, according to carefully structured conventions. The aim of these rules was to limit escalation, which two other factors contributed to. First, the institution of duel provided symmetry, as the two duelists or sides shared and pledged to subscribe to the same institution and norms. Second, the duel pitted the sides of a dyad against each other, thus strengthening the polarity between them. Symmetry and polarity led to duels being fought in a particular manner. As the parties recognized the same institution, they followed the same rules, which dictated what constituted victory and defeat. From this point of view, the ideas of limited war and decisive battle are directly comparable to a duel. Duels could thus lead to decision and become instruments of conflict resolution (Van Creveld 2009: 135).

The way in which Western military profession has sought to construct and fight war is not altogether different. As Holsti (2004: 283) describes, due to the standardization and institutionalization of war in the 18th century, war became

...an activity based on clear ideas about the appropriate role - and limits - of force in diplomatic relations. Numerous practices, organizational characteristics, training, and strategy became standardized across Europe, and hence patterned. The norms and rules of warfare were clearly specified in treaties, codes, war manuals, training routines, and public expectations.

Just like duel, war thus become an institution for conflict resolution that aims to achieve decision. As such, it too revolves around a coordination problem, a task solved by its institutionalization, as interaction in war becomes structured and prescribed. This not only helped attaining decision but, furthermore, provided a positive narrative and identity to the military profession, previously closely tied to the aristocracy and its leading societal role during times of both war and peace. Aside from a duel's role in upholding internal cohesion, it also provided opportunities for reconciliation. As Ute Frevert explains, duels were not the best way to exact revenge on an offending party, but a comparatively civilized instrument to reconcile with a potential friend (as the opponents in duels were always peers). The mutual danger during a duel was seen to purge all enmity between the duelists to the point that transformed an enemy into a friend. This kind of reconciliation was crucial in societies that did not yet differentiate people according to their functions (Frevert 1995: 23-24).

It was also important that this institutionalization and standardization developed war to a business between professionals who waged it in a professional manner, instead of hatred between people. This was important for both limiting war and achieving decision, when losers were treated honorably as equals and professional functionaries of a sovereign state, which alone possessed the right to wage war (Holsti 2004: 282).

Just as aristocrats of the 19th century who fought duels, even contemporary enemies may need to become friends tomorrow. This is necessary because wars should ultimately lead to peace and hence require the parties to recognize their opponents as more or less equals. Ideas of fairness, if not honor, continue to have a central place in the understanding of war held by the Western military profession. Ideally, reconciliation is possible after war as long as force was used for legitimate reasons and in ways considered honorable. Similarly, and as Schelling (2008: 120) observes, conventions also offer "a graceful way out" with "no enduring costs in refusing to compete". Conversely, and as discussed later, without adhering to the same institution of waging war, war offers no such way out and becomes perpetual.

Historically, the strengthening of the state led to the gradual decrease of private conflicts and use of violence stemming from personal honor, which then fed into the legitimization of the collective - the nation and the state (Malešević 2010). In this sense, war as a continuation of politics became indeed a duel between political bodies, whose honor could similarly be violated by their peers. From this perspective, there was little difference between a duelist and a soldier in the trenches of First World War. Both were bound by their honor and forced to risk their lives in combat because of prevailing norms (Kiernan 2016: 317-318). Herberg-Rothe (2011: 73-74) draws more direct links between duel and war in the case of Clausewitz's Bekenntnissdenskchrift:

A duelist is willing to accept death before dishonor because the
social norms that define dueling provide assurance that the
meaning of the act will be understood and respected, regardless of
the result. This kind of normative assurance is less easily applied
to war, but for Clausewitz it was clearly important that it could
be. War is recognizable as a duel in part because of the mutual
recognition of the belligerents, their acceptance of a shared
understanding of what they are doing... Analytically it is also a
prerequisite to his understanding of war as a political instrument.

This view of war as an institution thus underlines even Clausewitz's famous view of war as a continuation of 
politics, indispensable to modern military theory and practice alike. It is the mutually accepted institution that sets a limit for the use of violence in duels both between individuals and between communities, thus shackling extremities: the shared institution sustains symmetry between parties, defines the purpose and means of violence, as well as who can apply and be targeted by it (Herberg-Rothe 2009: 212). Simply put, a shared understanding of war between those waging it makes it much easier to use it for political ends, as it promises the possibility of decision. At the very least, the individual parties need to wage war according to their own norms to distinguish violence in war from other violence. As Jesse Glenn Gray contends, the "basic aim of a nation at war... is to distinguish as sharply as possible the act of killing from the act of murder by making the former into one deserving of all honor and praise" (Gray 1998 [1970]: 131-132). Failing to do so would not only threaten the existence of states, but even societies (Haldén and Jackson 2016), and result in anarchy that questions the idea of war as organized and instrumental violence. Without institutionalization, no war.

\section{The obsolete idea of the duel}

Comparing war to a duel emphasizes the temporal limits of war. Both in a duel and in war, shared norms allow reaching a decision, making it possible to resolve a conflict once and for all. In fact, the temporal delimitation of war underlies military profession, as shown by the notion that war is just an interruption of peace, which seeks a better peace through violent means. On the one hand, this provides space for the military profession to take responsibility for war during its duration (and the civilians to reassume control as soon as it ends). This is a requirement for professional autonomy, central for Samuel Huntington's (1957) influential thesis on civil-military relations. On the other hand, this interruption of peace also emphasizes the intimate relationship between force and war in the sense that violence must end before war can. If war is indeed a political instrument, it is necessary for political goals to be attained before peace can result. That said, these political goals need not to be the ones that existed at the outset of war, as they often develop during hostilities. Influenced by Napoleon, for Clausewitz, true war was about decision. Decision is established by making the enemy defenseless through the destruction of its means of resistance, or armed forces. After this, the opponent has no choice but to sue for peace. This absolute war, as Clausewitz called it, would always reign supreme against more limited forms of war (Gat 2001: 221).

This attainment of decision is the central strategic objective in war, and something that needs to be done as quickly as possible. This moment in a duel might arise when first blood is drawn (although it was not uncommon for duels too to escalate). Both institutions sought decision that was unquestionable, offering seemingly objective criteria that would translate violence to decision. Yet, ultimately, decision was only guaranteed by both sides' adherence to the same conventions. If one of them interpreted the outcome in a different way, decision was not guaranteed. While unrestricted escalation of violence might indeed lead to some decisive effects (such as in the case of Carthage), history itself is a process that to date has not stopped. Perhaps following Clausewitz (2004: 7), who warned that "the result in war is never absolute", Rupert Smith has questioned the idea of a decisive victory in contemporary conflicts. According to him, the boundary between war and peace has been blurred to the point that they have been replaced by a dynamic of confrontation and conflict. With force unable to play a decisive factor, these new dynamics lack a predefined linear sequence similar to the previous peace-crisis-war-resolution path (Smith 2008: 183). In other words, contemporary war is not as simple as a duel.

In his attempt to explain this development, Emile Simpson (2013: 234) sees that the "Clausewitzian war still works if its two prerequisites are generally satisfied: polarity and the containment of strategic audiences within the opposing sides". These two naturally reinforce each other. Yet, as Simpson continues (2013: 234), the prevailing circumstances have changed to the extent that these prerequisites are "typically compromised". While this observation regarding the circumstances is certainly correct, it would perhaps be better to suggest that the idea of war as an institution that resembles the duel - or any other kind of conceptualization - delivers decision as long as the opposing side too adheres to it, ${ }^{6}$ or as long as violence can be used in an unrestrained manner, hence making the opponent's nonadherence irrelevant. It is this latter point that has contributed to the idea that asymmetry in war is effective.

6 Schelling (2008: 137-138) suggests as much and is correct in his emphasis of traditions, past practices, and tacit understandings. Likely because Schelling focused on Western militaries and Simpson on contemporary conflicts, which typically involve non-Western belligerents, Schelling assumed symmetry and Simpson asymmetry between the opponents. 
Rupert Smith (2008: 6) has offered a thoughtful rebuttal of ideas of asymmetry. According to him,

The practice of war, indeed its 'art,' is to achieve an asymmetry over the opponent. Labelling wars as asymmetric is to me something of a euphemism to avoid acknowledging that my opponent is not playing to my strengths and I am not winning.

From this perspective, asymmetry is just something that does not correspond to deeply held conventions about war. This also explains why we cling to the countless principles of war offered during the past centuries. If asymmetry indeed was good, then these lists would surely need to be discarded. That this is not the case begs an explanation. One entails that while principles of war - effectively views of war shared by opposing sides - are good on higher levels, asymmetry on lower levels becomes more pronounced. Often asymmetry is required, especially against superior foes. Callwell's (1996: 405) observation from the Indian Rebellion of 1857 suggests as much: "the very fact that the rebels were organized after a fashion and fought somewhat in the European manner" meant that "there were formations to break, hostile squadrons to be swept away and guns to be captured". Unsurprisingly, the British crushed the uprising. The real lesson was how foolhardy and strategically unwise it was to adopt the same conventions as a stronger opponent, no matter how "gentlemanly" they were. As Conrad Crane (2013: 5) pithily observed, "there are two approaches to waging war, asymmetric and stupid".

Of course, one only needs to read Callwell's manual to see that his conventions would hardly be described gentlemanly today due to the prevalence of unrestrained violence. That these ideas have developed limitedly until recent times is clear from General Westmoreland's stance during the Vietnam War, where he described a "genuine problem": "commanders must exercise restraint unnatural to war and judgment not often required of young men" (quoted in Ward 2017: 128). Much evidence points to the fact that even in Vietnam, restraint remained tenuous. Partly because of expectations to limit violence, Western forces end up in a double bind when their opponents hold on to different views of war. Constrained by these expectations to limit the use of force, the old military ethos and conventions regarding war offer no easy way out. The reason for this can be found in Simpson's observation that when the enemy does not ascribe to the same template of war, it cannot easily be forced to accept a given narrative. In this sense, the opponent is more like a domestic political opponent that will never be fully persuaded by one's ideas, rather than a military opponent that needs to be subordinated through the traditional military instruments of death and destruction (Simpson 2013: 232-233). What this lack of shared norms then amounts to is a profound lack of decision and hence, clear-cut, victory.

When the idea of a clearly delineated war akin to the duel does not deliver decision any longer, one ends up in a situation where war escapes the narrow institutional boundaries that the military profession has set up for it. Simpson (2013) - a former officer - sees this as undesirable. Even others have been wary of war becoming a routine instead of a clearly delineated activity deserved for military professionals (Brooks 2016). While this has been the case in many modern conflicts, the weakness of the opponents in these has so far made it possible to ignore this development: Al-Qaeda, the Islamic State, and the Taliban can at best wreak havoc but not threaten the existence of Western states (even their success elsewhere has to date been limited). That said, it is far from certain that the political end states sought in these conflicts have been achieved either. So even if these opponents are not strictly speaking winning, they have often succeeded in denying victory for their Western adversaries, who, just like the aristocracy increasingly with the duel by the late 19th century, appear stuck with an institution that is increasingly becoming obsolete due to its poor utility in recent wars.

It conceivably only requires one powerful spoiler who possesses a different view on war - the role recently given to Russia's Vladimir Putin - to change the rules of the game for everyone. (Although it appears premature to equal Putin with figures like Adolf Hitler, Napoleon, and Shaka Zulu.) The mutually shared interest of limiting nuclear war during the Cold War, however, illustrates that even polarized opponents who perceive their relationship as a zero-sum game can find common ground and language to be able to construct institutions and norms that limit escalation (Schelling 1980; 2008). The question is however, whether this is possible today. Again, the duel becomes a way to discuss why.

Just like dueling was the privilege of the aristocracy, contemporary war in the West remains the sole right and responsibility of a dedicated military profession. The same idea of exclusivity exists in both institutions, in regard to certain social categories. The aristocracy's transformation into military professionals was in many ways a natural one. With changing societies where their status was increasingly questioned, it must have felt, to some extent, natural to dedicate oneself to military matters, which had for long belonged to aristocrats. As John Keegan (2014: 322) shrewdly observed, for killing to be gentlemanly, it needs to be done between gentlemen. 
Consider the duel and the professionalization of the military. While we tend to see duels as rational mechanisms for conflict resolution, their earlier focus was rather on the demonstration of honor. Simply put, it was more important to prove that one was willing to risk life and limb over honor, than to defeat one's opponent. Similar conceptualization can be seen in punitive campaigns or in wars fought "to punish an insult or to chastise a people who have inflicted some injury" (Callwell 1996: 27). The difference here is that whereas those slighting the great powers were hardly equal, those fighting duels should be - only equals who recognized each other could question each other's honor, which duel in turn would restore. Herberg-Rothe (2011: 80) argues that it was this dual construction that made duels limited affairs. Because duelists were of equal value, killing was deemed dishonorable, and even punishable by law. This contributed to deescalating violence.

What Clausewitz later came to contribute to was the process of professionalization of the military, which had started in the mid-18th century through defining war (Honig 2011, 2016, 2017; Gat 2001): the result of his idea of war as instrumental in nature resulted in a more rationalized and businesslike warfare. Finding violence as the new regulating principle in war as well as the element that set war apart from all other human endeavors, Clausewitz saw that it naturally fell within the purview of this new profession. This businesslike approach came best forward in the way Clausewitz viewed the 18th-century wars limited by societal norms and conventions as "imperfect" ones that were not done "right" as policy did not always take into consideration the needs of war (Honig 2011: 44). This perspective partly stems from the view of the military as an instrument of and for the state, where nationalism inevitably challenged previous conventions because of the notion of "my country right or wrong". Here, ideas connected to duel are visible in the way war was institutionalized. Yet, as shown by Clausewitz's quest for perfecting war, this rationalized understanding of war sought to disconnect violence from complex social relations, such as the various ways to ritualize violence (Blok 2001; Collins 2008) and politics in general. Ultimately, this rationalization became a core part of the process of military professionalization, formed around a shared institution of war that allowed establishing a bureaucracy tasked to wage it.

Gray argues that it is when hatred between people becomes abstract that limitations for violence are removed: enemies become deindividualized into a unified force of total evil that deserves neither mercy nor sympathy. Professional soldiers instead perceived war as a game in which those fighting it were simply doing their duty.
As long as they followed set rules, they were to be treated humanely after hostilities ceased (Gray 1998: 134-145). This notion enjoys wider support and was perhaps best captured by Jean Renoir's Le Grande Illusion, where aristocratic officers on opposing sides have more in common with each other, than with their own compatriots from lower classes. As Michael Howard noted, the aristocratic class possessed the right to bear arms, owned the activity of fighting, and shared similar conceptions of honor regarding the boundaries of war that had constrained violence in the 18th century (Howard 2004: 376). For instance, proponents of the duel drew from the same ideals of honor that were used to justify war. This had to do with the democratization of war, where rulers expanded aristocratic honor into national proportions. Ideas of dueling, always central to the aristocracy, played a major role in this (Kiernan 2016: 316).

Following his experience in the Second World War, Gray was skeptical whether such professional norms held any longer, describing them as "chivalric behavior" that was "grotesquely inappropriate" because of the increasingly totalitarian, if not postdemocratic, character of modern warfare (Gray 1998: 146-147). Later sociological literature (Malešević 2010) too confirmed that an opponent deemed "incapable of grasping civilized rules of warfare" was "sought out to be exterminated, not subdued" (Gray 1998: 149). As President Harry Truman (1945) wrote on the day the United States dropped its second atomic bomb in Japan, "The only language they seem to understand is the one we have been using to bombard them. When you have to deal with a beast you have to treat him as a beast. It is most regrettable but nevertheless true." While racism certainly contributed to stripping humanity from opponents, so did deviation from the institutions perceived legitimate: as Montaigne noted, "everyone calls barbarity that to which they are not accustomed". This translates to different kinds of means and ends that can be used against "uncivilized" opponents of the West, which would have been deemed illegitimate against equals. To name only a few examples, the use of poison gas was both debated and adopted in colonies during the interwar period when it was no longer used in Europe, and insurgencies were dealt with through genocide (Kramer 2008). Aside from violence - death and destruction - becoming the sole means of communication, it should not be taken for granted that contemporary ends are any less total than before.

Not adhering to the same institution of war thus risks escalation of violence due to lack of mutual recognition as professionals or even human beings. In other words, a shared institution - which regulates the conduct of the warring parties toward each other rather than civilians - could 
again have some limiting effect. For instance, first, the aristocracy and, later, the officer class found norms around the treatment of prisoners of war, enacted specifically for the purpose of limiting violence between those who fought. Naturally, it was only states - those recognized as equals - who could legitimately wage war in the first place (Schmitt 2011).

After the Second World War, wars of aggression have been eschewed upon, making fighting only justified in self-defense. Very few wars have been declared in the West, contributing to Martin Shaw's description of Western societies as postmilitary ones (1991). Nonstate actors and those fighting to achieve other goals are criminalized and are not to be negotiated with. More powerful spoilers, such as Russia, need to be punished but pose a more profound problem as they are difficult to coerce with violence alone. In some ways, ends have become stricter as some political projects are mutually incompatible to the point that the existence of one questions the other. Classic examples of opponents in the Second World War who fought each other in ways that differed from those used against others are offered by Hitler's Germany and the Soviet Union (Legro 1995), as well as Imperial Japan and the United States (Dower 1986). Yet, these conceptualizations of enmity are hardly absolute and immutable: witness how Germany and Soviet Union had cooperated during the interwar years, how the United States' perception of the Soviet Union changed from an ally to a mortal threat after the war, and the still-continuing alliance between the United States and Japan after the defeat of the latter.

Nevertheless, when they exist, these conceptualizations remain powerful. The best contemporary examples are offered by Al-Qaeda and the Islamic State, with which no political compromise seems possible at the time of writing. With these opponents, the means of war may not be total, even if the ends certainly are: just witness the limited Western efforts against the Islamic State, as well as the organization's continued attacks in areas it once controlled but has since lost. The lack of shared institutions thus leads to the lack of recognition and, thus, at best, to an ambiguous peace because both the opponent's means and ends are perceived to lack legitimacy. Uncompromising belligerents will not accept any verdict save complete destruction. This results in unstable victories, which require further force to maintain and, hence, potentially perpetual war.

While the idea of war without end may sound terrible, the wars of the past century to some extent confirm Émile Durkheim's (2013: 208ff) observation that it is organisms that are more alike which fight fiercest. After all, one just needs to compare the world wars to the recent wars in Afghanistan and Iraq to understand that past conflicts with clear endings have been much more destructive than the more limited contemporary ones. Despite the destructiveness of the world wars, they ultimately led to decision and peace because the belligerents understood war in the same way and thus followed the same conventions. This is not the case in many contemporary conflicts, where peace remains a distant prospect. If there is anything positive in the current situation, it is that while the West may not be winning in these conflicts, it is hardly losing either. The question is, should we not aim for more?

\section{Conclusions}

This article has heuristically used the duel as a way to explore the normative dimension of war, found in the institution that forms the foundation of the Western military profession. Investigating this dimension is important, considering that perception of war permeates all aspects of war, from its start to long after it has ended. Views of war held by the Western military profession and replicated in military training programs also offer one way to explain why the West struggles with contemporary wars. Whereas much of this discussion has argued that it is liberal norms that prevent escalation of violence and hence restrain the military from winning (Merom 2007), this paper has attempted to highlight deeper issues within the profession itself. Ultimately, this questions the common notion that without political interference, military establishments would be more successful in these conflicts.

Simply put, the core problem is that the Western military profession has acquired shared conventions about war and warfare that are fundamentally different from those held by their opponents. These disparate views of war held in the West - whose construct of war is akin to a duel rationalized in order to detach it from complex social relations - and elsewhere form perhaps the biggest asymmetry in contemporary war. This rationalization has led to rigidness regarding how to define war and how it should be waged at the cost of adaptability and breadth. This, in turn, has led to lack of mutual understanding and recognition and, ultimately, lack of decision. Lack of mutual recognition causes existential war, whereas the lack of decision in turn leads to its perpetuation. While Honig has suggested that parties can successively learn from each other to merge their norms to the point that allows one or the other side to win (Angstrom forthcoming), few of the recent wars where Western forces have fought have led to such victories. Instead, what seems to have become the norm is a peace fundamentally ambiguous due to lack of recognition regarding the 
legitimacy of both means and goals. This results in unstable victories, which require further force to maintain. No matter how tempting a return to the past may appear, rethinking of professional norms is urgently needed.

Finally, although this paper has investigated norms of the Western military profession, it has left the other side of the equation, or the comparable views of war held by their opponents, uninvestigated. Here, I disagree with Holsti, who sees most wars after 1945 as displaying "few characteristics associated with patterns of social action", leading to wars that "have broken out almost randomly" and where "strategy and tactics follow few rules and resemble opportunism of an extreme kind" (Holsti 2004: 287). Holsti's Eurocentric bias leads him to perceive that these patterns of social action only concerned those closely connected to the idea of war serving a sovereign state. Yet, whether such a state exists or not, the idea of war as an institution logically presupposes the existence of conventions regarding it. Although this article has exclusively focused on Western military professionalism, investigating these non-Western views of war thus opens not only an interesting, but equally important, venue for future research, where the cultural sociology of war has much to offer.

\section{Acknowledgments}

An early draft of this article was presented at ISAC-ISSS Annual Conference 2016 at the University of Notre Dame, Indiana, where the author's participation was supported by Swedish Armed Forces' FoT (Forskning och Teknikutveckling) grant. The views expressed in this article however belong solely to the author.

\section{References}

Alexander, A. (2007). The genesis of the civilian. Leiden Journal of International Law, 20, pp. 359-376.

Angstrom, J. (Forthcoming). Reviewing different understandings of victory and defeat in war. International Studies Review.

Angstrom, J., and Widen, J. (2016). Religion or reason? Exploring alternative ways to measure the quality of doctrine. Journal of Strategic Studies, 39(2), pp. 198-212.

Bacevich, A. (1995). The use of force in our time. The Wilson Quarterly, 19(1), pp. 50-63.

Beckett, I. (2001). Modern Insurgencies and Counter-Insurgencies: Guerrillas and Their Opponents since 1750. Routledge, London.

Berman, N. (2004). Privileging combat? Contemporary conflict and the legal construction of war. Columbian Journal of Transnational Law, 43(1), pp. 1-72.

Biddle, S. (2004). Military Power: Explaining Victory and Defeat in Modern Battle. Princeton University Press, Princeton.

Blok, A. (2001). Honour and Violence. Polity, Cambridge.
Brooks, R. (2016). How Everything Became War and the Military Became Everything: Tales from the Pentagon. Simon \& Schuster, New York.

Callwell, C. (1996 [1906]). Small Wars: Their Principles \& Practice. University of Nebraska Press, Lincoln.

Clausewitz, C. (2004). On War. Barnes \& Nobles, New York.

Clausewitz, C. (2015). Clausewitz on Small War. Translated by Christopher Daase and James Davis. Oxford University Press, Oxford.

Collins, R. (2008). Violence: A Micro-Sociological Theory. Princeton University Press, Princeton, N.J.

Crane, C. (2013). The lure of strike. Parameters: Journal of the US Army War College, 43(2), pp. 5-12.

Departementenes sikkerhets- og serviceorganisasjon [Norwegian Government Security and Service Organisation]. (2016). En God Alliert - Norge I Afghanistan 2001-2014 [A Good Ally - Norway in Afghanistan 2001-2014]. Norges offentlige utredninger, Oslo. Available at https://www.regjeringen.no/contentassets/09faceca099c4b8bac85ca8495e12d2d/no/pdfs/ nou201620160008000dddpdfs.pdf

Douglas, M. (1986). How Institutions Think. Syracuse University Press, Syracuse.

Dower, J. (1986). War Without Mercy: Race \& Power in the Pacific War. Faber, London.

Duffy, C. (1987). The Military Experience in the Age of Reason. Routledge \& Kegan Paul, London/New York.

Durkheim, É (2013). The Division of Labour in Society, 2nd edn. Palgrave Macmillan, Basingstoke.

Echevarria, A. (2013). Clausewitz \& Contemporary War. Oxford University Press, Oxford.

Farrell, T. (2005). Norms of War: Cultural Beliefs and Modern Conflict. Lynne Rienner, Boulder.

Frevert, U. (1995). Men of Honour: A Social and Cultural History of the Duel. Translated by Anthony Williams. Polity Press, Cambridge.

Gat, A. (2001). A History of Military Thought: From the Enlightenment to the Cold War. Oxford University Press, Oxford.

Gow, J. (2005). Defending the West. Polity Press, London.

Gray, J. G. (1998). The Warriors: Reflections on Men in Battle. University of Nebraska Press, Lincoln, NE.

Haldén, P., and Jackson, P. (2016). Introduction: Symbolic and mythological perspectives on war and peace join the archaic with the modern. In: Haldén, P., and Jackson, P. (eds.), Transforming Warriors: The Ritual Organization of Military Force. Routledge, London/New York, pp. 1-18.

Herberg-Rothe, A. (2009). “Clausewitz's 'wondrous trinity' as a coordinate system of war and violent conflict. International Journal of Conflict and Violence, 3(2), pp. 204-219.

Herberg-Rothe, A. (2011). The state and the existential view of war. In: Herberg-Rothe, A., Honig, J. W., and Moran, D. (eds.), Clausewitz: The State and War. Franz Steiner Verlag, Stuttgart, pp. 71-86.

Heuser, B. (2010a). The Strategy Makers: Thoughts on war and society from Machiavelli to Clausewitz. Praeger, Santa Barbara, CA.

Heuser, B. (2010b). "Small wars in the age of Clausewitz: The watershed between partisan war and people's war. Journal of Strategic Studies, 33(1), pp. 139-162.

Holland, T. (ed.) (1917). De Bello, De Represaliis et De Duello by Giovanni Da Legnano. Oxford University Press, Oxford.

Holsti, K. (2004). Taming the Sovereigns: Institutional Change in International Politics. Cambridge University Press, Cambridge. 
Honig, J. W. (2011). Clausewitz and the politics of early modern warfare. In: Herberg-Rothe, A., Honig, J. W., and Moran, D. (eds.), Clausewitz: The State and War. Franz Steiner Verlag, Stuttgart, pp. 29-48.

Honig, J. W. (2016). The tyranny of doctrine and modern strategy: Small (and large) states in a double bind. Journal of Strategic Studies, 39(2), pp. 261-279.

Honig, J. W. (2017). Uncomfortable visions: The rise and decline of the idea of limited war. In: Wilkinson, B., and Gow, J. (eds.), The Art of Creating Power: Freedman on Strategy. Hurst, London, pp. 29-48.

Honig, J. W., and Käihkö, I. (2014). The likely lads: The joint SwedishFinnish PRT in Mazar-e Sharif. In: Chiari, B. (ed.), From Venus to Mars? Provincial Reconstruction Teams and the European Military Experience in Afghanistan, 2001-2014. Rombach, Freiburg, pp. 209-220.

Howard, M. (2001). War in European History, Updated edn. Oxford University Press, Oxford.

Howard, M. (2004). “Total war: Some concluding reflections. In: Chickering, R., Förster, S., and Greiner, B. (eds.), A World at Total War: Global Conflict and the Politics of Destruction, 1937-1945. Cambridge University Press, Cambridge, pp. 375-383.

Huntington, S. (1957). The Soldier and the State - the Theory and Politics of Civil-Military Relations. Belknap Press of Harvard University Press, Cambridge, MA.

Joint Chiefs of Staff. (June 16, 1995). “JP 3-07: Joint Doctrine for Military Operations Other Than War”. Joint Warfighting Center, Washington, DC.

Käihkö, I. (2018). Constructing war in West Africa (and beyond). Comparative Strategy, 37(5).

Keegan, J. (1994). A History of Warfare. Alfred A. Knopf, New York.

Keegan, J. (2014). The Face of Battle: A Study of Agincourt, Waterloo and the Somme. Penguin, London.

Kennedy, D. (2006). Of War and Law. Princeton University Press, Princeton.

Kiernan, V. (2016). The Duel in European History: Honour and the Reign of Aristocracy. Zed Books, London.

Kramer, A. (2008). Dynamic of Destruction: Culture and Mass Killing in the First World War. Oxford University Press, Oxford.

Lederer, E. (2006). On the sociology of world war. European Journal of Sociology, 47(2), pp. 241-268.

Legro, J. (1995). Cooperation Under Fire: Anglo-German Restraint During World War Il. Cornell University Press, Ithaca.

Malešević, S. (2010). The Sociology of War and Violence. Cambridge University Press, Cambridge.

McNeill, W. H. (1983). The Pursuit of Power: Technology, Armed Force, and Society since A.D. 1000. Blackwell, Oxford.

Merom, G. (2007). "The origins and implications of western counterinsurgency failures. In: Angstrom, J., and Duyvesteyn, J. (eds.), Understanding Victory and Defeat in Contemporary War. Routledge, London, pp. 168-186.

Miller, S. (2010). The Moral Foundations of Social Institutions: A Philosophical Study. Cambridge University Press, New York.

Mogelson, L. (2013). “Which Way Did the Taliban Go?” The New York Times Magazine. Available at http://www.nytimes. com/2013/01/20/magazine/which-way-did-the-taliban-go.html.

Neff, S. (2008). War and the Law of Nations: A General History. Cambridge University Press, Cambridge.

Oxford English Dictionary. (2002). Military, adj. and n. Available at http://www.oed.com/view/Entry/118428
Oxford English Dictionary. (2016). Duel, n. Available at http://www. oed.com/view/Entry/58242

Paret, P. (2007). Clausewitz and the State: The Man, His Theories, and His Times. Princeton University Press, Princeton, N.J.

Ralston, D. (1990). Importing the European Army: The Introduction of European Military Techniques and Institutions into the Extra-European World, 1600-1914. University of Chicago Press, Chicago.

Regeringen [Swedish Government]. (2017). Sverige i Afghanistan 2002-2014 [Sweden in Afghanistan 2002-2014]. SOU 2017:16.

Schelling, T. (1980). The Strategy of Conflict. Harvard University Press, Cambridge, MA.

Schelling, T. (2008). Arms and Influence. Yale University Press, New Haven and London.

Schmitt, C. (2011). Writings on War. Polity Press, Cambridge.

Shaw, M. (1991). Post-Military Society. Polity Press, Oxford.

Simpson, E. (2013). War from the Ground up: Twenty-First Century Combat as Politics. Oxford University Press, Oxford.

Smith, P. (2005). Why War? The Cultural Logic of Iraq, the Gulf War, and Suez. Chicago University Press, Chicago.

Smith, R. (2008). The Utility of Force: The Art of War in the Modern World. Vintage, New York.

Strachan, H. (2006). A general typology of transcultural wars - The modern ages. In: Kortüm, H. H. (ed.), Transcultural Wars: From the Middle Ages to the 21st Century. Akademie Verlag, Berlin, pp. 85-103.

Strachan, H. (2013). The Direction of War: Contemporary Strategy in Historical Perspective. Cambridge University Press, Cambridge.

Truman, H. (1945). "Harry Truman to Samuel McCrea Cavert." Shapell. Available at http://www.shapell.org/manuscript/ truman-defends-use-of-atomic-bomb-against-japan.

Ucko, D. (2012). "Whither counterinsurgency: The rise and fall of a divisive concept. In: Rich, P. B., and Duyvesteyn, I. (eds.), The Routledge Handbook of Insurgency and Counterinsurgency. Routledge, London, pp. 67-79.

Van Creveld, M. (2009). The Culture of War. Spellmount, Brimscombe Port.

Vardi, G. (2010). Joachim von Stülpnagel's military thought and planning. War in History, 17(2), pp. 193-216.

Ward, G. (2017). The Vietnam War: An Intimate History. Alfred A. Knopf, New York.

Wishon, M. (2013). German Forces and the British Army: Interactions and Perceptions, 1742-1815. Palgrave Macmillan, New York.

\section{Author biography}

Ilmari Käihkö is an assistant professor at the Department of Security, Strategy and Leadership, Swedish Defence University, and at the time of writing a post-doctoral researcher at the Department of Sociology, Uppsala University, and a visiting fellow at the Department of Anthropology, Yale University, supported by the Ryoichi Sasakawa Young Leaders Fellowship Fund (SYLFF). He has worked as Veteran of the Finnish Defence Forces for two and a half years in West, Central and East Africa and Ukraine. Specialized in contemporary conflicts and cultural sociology of war, he is also interested in conflict ethnography, or the ethnographic methods that contribute to the investigation of these issues. 